\title{
Occurrence of Lactose Intolerance among Ethiopians
}

\author{
Habtamu LD ${ }^{1 *}$, Ashenafi $\mathbf{M}^{2}$, Taddese $\mathrm{K}^{3}$, Birhanu $\mathrm{K}^{1}$ and Getaw $\mathrm{T}^{4}$ \\ ${ }^{1}$ Wolaita Sodo University, PO Box 128, Wolaita Sodo, Ethiopia \\ ${ }^{2}$ Addis Abba University, College of Veterinary Medicine and Agriculture, Ethiopia \\ ${ }^{3}$ Ethiopian Development Research Institute, Ethiopia \\ ${ }^{4}$ International Food Policy Research Institute, Ethiopia
}

\begin{abstract}
Milk has been known as nature's most complete Food. Among the components of milk is lactose. Some people who lack the enzyme needed to digest lactose suffer from lactose intolerance and therefore cannot digest milk. Worldwide, nearly 70 percent of the adult population is thought to be lactose intolerant, and the condition is very common among American Indians and those of Asian, African, Hispanic, and Mediterranean descent. Lactose intolerance is one of the factors affecting milk demand and consumption, which subsequently influencing milk market/ productivity. But no information is available on lactose intolerance in Ethiopia. Therefore, this paper is the first attempt to study the incidence of lactose intolerance in the country. The aim of the paper, therefore, was to generate information on lactose intolerance through case study approach including questionnaire survey and document analysis. In the case study area of Ada district of Eastern Shoa of Ethiopia, out of 188 households/individuals surveyed, $7.45 \%$ of the respondents reported that they don't consume milk but consume fermented milk ('Ergo'). The majority reported symptoms of lactose intolerance ( $71.4 \%$ get vomiting upon consuming milk, $28.6 \%$ feel abdominal pain). The percentage of occurrence of lactose intolerance found in the survey is believed to affect the milk consumption in the country. Dairy processors need to make yoghurt or remove lactose, for consumers with special dietary requirements/lactose intolerance/to improve milk consumption. Awareness about lactose intolerance also needs to be created in the society by health extension workers.
\end{abstract}

Keywords: Milk consumption; Lactose intolerance; Lactose-free milk products; Ethiopians

\section{Introduction}

Milk has been known as nature's most complete Food. More than 100 different components have been identified in cow's milk. Intake of cow's milk and milk products contributes to health throughout life. Experimental studies indicate that cow's milk protein may help to increase bone strength, enhance immune function, reduce blood pressure and risk of some cancers, and protect against dental caries. Milk fat is also a source of energy, essential fatty acids (linoleic and linolenic), fat-soluble vitamins (A, D, E, and K), and several health-promoting components such as conjugated linoleic acid, sphingomyelin, and butyric acid. For example, emerging scientific findings reveal that CLA may protect against certain cancers and cardiovascular disease, enhance immune function, and reduce body fatness/increase lean body tissue. Milk and other dairy foods are an important source of many vitamins (riboflavin, vitamin B12 and vitamin A) and minerals (calcium, phosphorus, potassium, zinc, magnesium). A sufficient intake of calcium helps to reduce the risk of osteoporosis, hypertension, some cancers, and some types of kidney stones, and may have a beneficial role in weight management [1-3]. Milk lipids also contribute to the palatability of the diet [4].

Billions of people around the world consume milk and dairy products every day. Not only are milk and dairy products a vital source of nutrition for these people, they also present livelihoods opportunities for farmers, processors, shopkeepers and other stakeholders in the dairy value chain. But to achieve this, consumers, industry and governments need up-to-date information on how milk and dairy products can contribute to human nutrition and how dairying and dairy-industry development can best contribute to increasing food security and alleviating poverty [5].

Despite the slow growth seen in developing countries, the ILRI, along with other agencies, projected that the demand for dairy and dairy products will more than double in developing countries by the year 2025 with an estimated annual growth in consumption of $3.3 \%$ per year. This period of growth is referred to as the Livestock Revolution and is based on the projected increase in demand through population growth, urbanization and increased income generation. With this growth there will be changes in eating habits. Urban populations are also more likely to include milk and meat products in their diets based on their preference for increased variety and convenience [6,7].

In order to keep up with this increase in demand, there has been a push to focus on a more productive and market oriented dairy system throughout developing countries. A variety of international organizations such as Land O'Lakes, Send a Cow, and Heifer Project International have been working to promote milk production in SSA with the objectives of improving nutrition through increased milk consumption and increasing income generation for smallholder dairy farmers. Among the constraints and challenges of dairy development in developing countries is promotion of marketing and consumption of milk and dairy products [8].

Dairy production is one of livestock production system prevalent in Ethiopia. The urban and peri-urban milk production systems are major milk suppliers to urban areas. Considering the important prospective for smallholder income generation and employment opportunities from the high value dairy products, the development of the dairy sector can contribute immensely to poverty alleviation and improved nutrition in the country [9]. The per capita consumption of milk estimated at $19 \mathrm{~kg}$, which is lower than African averages of $27 \mathrm{~kg} /$

*Corresonding author: Habtamu Lemma Didanna, Wolaita Sodo University, PO Box 128, Wolaita Sodo, Ethiopia, Tel: 251465514417; E-mail: abebeh09@gmail.com

Received September 04, 2015; Accepted September 29, 2015; Published October 05, 2015

Citation: Habtamu LD, Ashenafi M, Taddese K, Birhanu K, Getaw T (2015) Occurrence of Lactose Intolerance among Ethiopians. J Food Process Technol 6 : 505. doi:10.4172/2157-7110.1000505

Copyright: (C 2015 Habtamu LD, et al. This is an open-access article distributed under the terms of the Creative Commons Attribution License, which permits unrestricted use, distribution, and reproduction in any medium, provided the original author and source are credited. 
year [10]. In addition, dairy production in Ethiopia is anticipated to increase rapidly in response to the fast growing demand for livestock products resulting from increasing human population, especially in urban areas, and rising consumer income, which is an opportunity for dairy producers in sourcing their livelihoods. However, among the potential factors affecting milk demand are lactose intolerance and fasting season, which subsequently influencing milk consumption/ nutrition security and livelihoods.

Worldwide, nearly 70 percent of the adult population is thought to be lactose intolerant, and the condition is very common among American Indians and those of Asian, African, Hispanic, and Mediterranean descent [11]. But no information is available on lactose intolerance in Ethiopia and there exist gap in the research and literature. Therefore, this paper is the first attempt to know the incidence of lactose intolerance in the country.

The aim of this paper, therefore, was to address information on lactose intolerance through case study approach including interviews and document analysis. Brief questionnaire survey of 188 households/ individuals was made for the case study (Table 1) in Ada district of Eastern Shoa of Ethiopia, which is one of the largest market-oriented dairy producing areas.

\section{Milk Composition/Lactose}

The nutritional value of milk is mainly determined by water, protein, fat, sugar (lactose), vitamins, and micronutrients [12]. The disaccharide lactose comprises $4.8-5.2 \mathrm{wt} \%$ of milk. In addition to its nutritional relevancy, the determination of lactose is important for people with lactose intolerance [13]. In Ethiopia, there are various figures on lactose content of cattle milk including $4.53 \%$ [14]; $4.18 \%$ for Boran-Friesian cross and $4 \%$ for Borana cows [15]; 5.17\% for crossbred and $5.29 \%$ local cows [16].

Cow milk contains approximately $5 \mathrm{~g}$ of lactose $/ 100 \mathrm{~g}$. As well as providing energy, lactose (along with milk oligosaccharides) supports growth, aids in softening of stools and enhances water, sodium and calcium absorption [17].

Lactose must be broken down by lactase (an enzyme/ $\beta$-galactosidase found in the intestine) before the body can use it. If there is not enough lactase, undigested milk sugar remains in the intestine. Bacteria in the colon then ferment this sugar. Gas, cramping, diarrhea, nausea, and vomiting can follow. Most of us begin to lose intestinal lactase as we age. Lactose intolerance occurs around 3-5 years of age and primarily

\begin{tabular}{|c|c|c|c|c|}
\hline SNo. & Age & Sex & Symptoms & Residence \\
\hline 1 & $1 \mathrm{yr}$ and 5 months & $\mathrm{F}$ & Vomiting & Town \\
\hline 2 & $19 \mathrm{yr}$ & $M$ & Abdominal pain & $"$ \\
\hline 3 & $21 \mathrm{yr}$ & $M$ & " & $"$ \\
\hline 4 & $60 \mathrm{yr}$ & $\mathrm{F}$ & Vomiting & $"$ \\
\hline 5 & $15 \mathrm{yr}$ & $M$ & " & $"$ \\
\hline 6 & NA & M & $"$ & $"$ \\
\hline 7 & $25 \mathrm{yr}$ & $\mathrm{F}$ & " & $"$ \\
\hline 8 & $18 \mathrm{yr}$ & $\mathrm{M}$ & Vomiting & Rural \\
\hline 9 & $6 \mathrm{yr}$ & M & Abdominal pain & $"$ \\
\hline 10 & NA & NA & Vomiting & , \\
\hline 11 & $38 \mathrm{yr}$ & $\mathrm{F}$ & " & $"$ \\
\hline 12 & NA & NA & Vomiting and Abdominal pain & $"$ \\
\hline 13 & $12 \mathrm{yr}$ & $\mathrm{F}$ & Vomiting & $"$ \\
\hline 14 & $51 \mathrm{yr}$ & $M$ & Diarrhea & $"$ \\
\hline
\end{tabular}

Table 1: Information on respondents found to have lactose intolerance (out of 188 people participated in the case study). affects adults. Cows'. This loss of intestinal lactase activity is not a disease, but rather a normal pattern in human physiology and is transmitted by a recessive gene [18].

Fermented milk products may be better tolerated by people with lactose intolerance, primarily because they contain less lactose [19]. In particular, yoghurt containing live bacteria may be better tolerated by lactose malabsorbers because of the $\beta$-galactosidase in the yoghurt or the presence of bacteria in the yoghurt that produce $\beta$-galactosidase in the small intestine. Furthermore, yoghurt takes longer to pass through the digestive system than does milk, thus allowing more effective breakdown of lactose [20]. In other words, the bacteria in the yoghurt partially digest the lactose into glucose and galactose (and the glucose to lactic acid); in addition, yoghurt's semisolid state slows gastric emptying and gastrointestinal transit, resulting in fewer symptoms of lactose intolerance [21,22]. Aged cheeses tend to have lower lactose content than other cheeses and, thus, may also be better tolerated. Predigested milk or dairy products with lactase are available in some countries and will often permit a lactose-intolerant individual to be able to take some or all milk products freely [21].

A promising recent development is the introduction of a new lactose-free dairy drink produced by a special filtration process that removes half of the milk lactose. A lactase enzyme is then added to the milk to break down the remaining milk sugars into simpler forms that the body can absorb. The ability to remove lactose from milk and milk products could capture the non-trivial market share of people who are lactose intolerant. Lactose-free milk could be an important factor, driving higher milk consumption [23]. This includes Lactose-free milk such as GalactominTM and lactose-hydrolyzed milk are prepared (from fungal lactase) for people suffering from lactose intolerance [24].

\section{Lactose Intolerance}

Lactose intolerance is the inability to digest lactose into its constituents, glucose and galactose, because of low levels of lactase enzyme in the brush border of the duodenum [25]. Lactose intolerance is defined as a metabolic disorder when people are unable to digest significant amounts of lactose due to the genetically insufficient production of the lactase enzyme ( $\beta$-galactosidase).

In adults with lactase deficiency (also called lactase nonpersistance, LNP), lactose is not digested in the upper bowel and reaches the lower bowel, where it is fermented by gut micro-organisms, which produces hydrogen, carbon dioxide and methane gas. Undigested lactose also draws water into the intestinal lumen through its osmotic effect, which increases motility and can cause diarrhoea. Symptoms include abdominal pain, bloating and flatulence. Thus, low lactase levels cause lactose malabsorption (or lactose maldigestion). When lactose malabsorption gives rise to symptoms, this is called "lactose intolerance", i.e. lactose malabsorption is the physiologic problem that manifests as lactose intolerance [21].

\section{Lactose intolerance and its prevalence in other countries}

Lactase deficiency in adults is a normal developmental phenomenon characterized by the down-regulation of lactase activity, which occurs soon after weaning in most ethnic groups [26]. Lactose maldigestion increases with age during adulthood [6]. The lactase persistence trait is more common in populations that practice cattle herding and dairying [27], and is related to genetic selection of individuals with the ability to digest lactose [21].

Children of some ethnic groups commonly lose lactase at one to 
two years of age (e.g. Thai children) while in others lactase persists until later in life (10-20 years of age) (e.g. Finnish children) [28,29]. According to some estimates, approximately 70 percent of the world's population has primary lactase deficiency [21].

Problems of lactose intolerance are especially severe in African and Asian populations. In Asia, more than half of the population is believed to have some form of lactose intolerance [22].

The frequency and intensity of lactose intolerance/malabsorption varies widely among populations from _ $100 \%$ in south-east Asia to 5\% in north-west Europe [30,31]. Lactose deficiency in Europe has been reported to vary between $4 \%$ (Denmark and Ireland) and 56\% (Italy) [32]. In India, the frequency of lactase persistence is higher in the north than the south, and in the rest of the world, lactase persistence frequency is generally low. In Africa, the distribution is patchy, with some pastoralist nomadic tribes having high frequencies of lactase persistence compared with the neighbouring groups inhabiting the same country [33], with a similar pattern observed between Bedouin and neighbouring populations in the Middle East [34,35].

\section{Symptoms of lactose intolerance}

People who have either primary or secondary lactase deficiency are lactose intolerant, as judged by a lactose tolerance test, and may exhibit symptoms of lactose intolerance [36].

The symptoms of lactose intolerance due to lactose malabsorption and caused when milk is consumed by a lactase non-persistent person, vary greatly from person to person, but if they are evident, they usually manifest themselves within 1-2 $\mathrm{h}$ of ingestion. Ingestion of dairy products resulting in symptoms of lactose intolerance generally leads to transient symptoms without causing harm to the gastrointestinal tract [21].

\section{Diagnosis of lactose intolerance}

Several indirect methods have been developed for the purpose of diagnosis, all of which utilise lactose digestion to inform on an individual's lactose tolerance status, and by implication lactase persistence status. The general practice is to give a lactose load after an overnight fast. The two most widely used methods are described below [32].

\section{Diagnosis of lactase non-persistence/persistence}

The blood glucose test: A baseline measurement of blood glucose is taken before ingestion of a lactose load, and then at various time intervals (usually every $30 \mathrm{~min}$ ) for the following $2 \mathrm{~h}$. An increase in blood glucose indicates lactose digestion (lactase cleaves the lactose molecules into glucose and galactose, allowing absorption into the bloodstream and subsequent detection), and no increase, or a 'flat line', is indicative of a lactose non-digester/maldigester or intolerant phenotype [32]

The breath hydrogen test: Undigested lactose remains in the intestine and is fermented by colonic bacteria, producing hydrogen gas, carbon dioxide, and methane in some individuals. A portion of the hydrogen produced in the colon diffuses into the blood and is excreted via the lungs. The breath test measures the excretion of this hydrogen. Typically, a subject is given an oral dose of lactose following an overnight (12 h) fast. Breath samples are collected at regular intervals for a period of $5-8 \mathrm{~h}$ and analyzed by gas chromatography. The historical test used $50 \mathrm{~g}$ of lactose as a challenge dose, and an increase of 20 parts per million (p.p.m.) or greater above the fasting level as an indicator of lactose maldigestion. More recently, it has been shown that using a sum of hydrogen from hours 5, 6, and 7 and a _ 15 p.p.m. above-fasting criterion for maldigestion resulted in $100 \%$ sensitivity and specificity for carbohydrate maldigestion [36].

\section{Concluding Remarks}

Lactose intolerance is one of the factors affecting milk market demand and subsequently milk productivity. To bridge the gap of information on incidence of lactose intolerance, a survey was conducted in Ada'a district of Ethiopia, which is among the largest market-oriented dairy producing areas. $7.45 \%$ of the respondents reported that they don't consume milk but consume fermented milk ('Ergo'). The majority reported that they get vomiting upon consuming milk, and feel abdominal pain. The percentage of occurrence of lactose intolerance found in the survey is believed to affect the milk consumption in the country $[37,38]$.

With the above concluding remarks, the following recommendations were drawn:

I. A large scale national study that assess wider population with more elaborate clinical diagnosis need to be done in future studies to know the exact prevalence/ distribution of lactose intolerance in the country. Lactase activity is usually assessed indirectly from measurements of lactose absorption via breath tests. Measurement of the hydrogen in the breath after taking lactose is a useful test because large amounts of hydrogen indicate that lactose is not being fully digested [36].

II. Dairy processors need to make yoghurt or remove lactose/lactose-free milk for consumers with special dietary requirements/lactose intolerance to improve milk consumption.

III. Awareness about lactose intolerance needs to be created among the society by health extension workers.

IV. Taking lactase tablets or drops, such as Lactaid or Dairy Ease is an option, which contain the enzyme that breaks down lactose, reducing the amount that your body must digest on its own are among the dietary strategies effectively manage lactose intolerance [36].

\section{References}

1. Mc Carron DA, Heaney RP (2004) Estimated healthcare savings associated with adequate dairy food intake. Am J Hypertens 17: 88-97.

2. Huth PJ, DiRienzo DB, Miller GD (2006) Major scientific advances with dairy foods in nutrition and health. J Dairy Sci 89: 1207-1221.

3. Jarvis JK, Lois D, Mc Bean GDM (2007) Handbook of Dairy Foods and Nutrition. 3rd eds. National Dairy council. CRC Press, USA.

4. Taylor MW, MacGibbon AH (2002) Lipids. Elsevier Sc. Ltd, New Zealand.

5. FAO (2013) Milk and dairy products in human nutrition, Rome, Italy.

6. Delgado C, Rosegrant M, Steinfeld H, Ehui S, Courbois C, et al. (1999) Livestock to 2020: The Next Food Revolution. Food Agriculture and the Environment Discussion Paper 28. International Food Policy Research Institute, Washington, D.C, USA.

7. Thorpe W, Muriuki HG, Omore A, Owango MO, Staal S, et al. (2000) Development of smallholder dairying in Eastern Africa with particular reference to Kenya.

8. Ndambi O, Hemme T, Latacz-Lohmann U (2007) Dairying in Africa-Status and recent developments. Livestock Research for Rural Development.

9. Ahmed MM, Ehui S, Assefa Y (2004) Dairy development in Ethiopia. IPFRI- 
Citation: Habtamu LD, Ashenafi M, Taddese K, Birhanu K, Getaw T (2015) Occurrence of Lactose Intolerance among Ethiopians. J Food Process Technol 6: 505. doi:10.4172/2157-7110.1000505

Page 4 of 4

EPTD, Discussion paper 123, Environment and production technology division. Washington DC, USA.

10. FAOSTAT (2009) FAO statistical yearbook. Rome: Food and Agriculture Organization of the United Nations.

11. (2002) Encyclopedia of Foods: A guide to Healthy Nutrition. Dole Food Company, Inc. Published by Elsevier 3.

12. Walstra P, Wouters JTM, Geurts TJ (2006) Dairy Science and Technology. CRC Taylor \& Francis Group, New York.

13. Rasooly A, Herold KE (2011) Biosensors. Elsevier Ltd. Encyclopedia of dairy sciences, USA.

14. Nebiyu R (2008) Traditional and improved milk and milk products handling practices and composition and microbial quality of raw milk and butter in Delbo watershed area of Wolaita zone. Hawassa University, Ethiopia.

15. Mesfin R, Getachew A (2007) Evaluation of grazing regimes on milk composition of Borana and Boran-Friesian crossbred dairy cattle at Holetta research center, Ethiopia. Livestock Research for Rural Development.

16. Alemu S, Tamiru F, Almaw G, Tsega A (2013) Study on bovine mastitis and its effect on chemical composition of milk in and around Gondar Town, Ethiopia. Journal of Veterinary Medicine and Animal health 5: 215-221.

17. Hernandez-Ledesma B, Ramos M, Gomez-Ruiz JA (2011) Bioactive components of ovine and caprine cheese whey. Small Ruminant Res 101: 196204.

18. Campbell GM (2003) Aerated foods. Encyclopedia of food science and nutrition. Academic Press, USA.

19. Panesar PS (2011) Fermented dairy products: starter cultures and potential nutritional benefits. Food Nutr Sci 2: 47-51.

20. Buttriss J (1997) Nutritional properties of fermented milk products. Int J Dairy Technol 50: 21-27.

21. Heyman MB (2006) Lactose intolerance in infants, children, and adolescents. Pediatrics 118: 1279-1286.

22. Encyclopedia of Dairy Sciences (2011) (2ndedn), Elsevier Ltd. USA

23. OECD/FAO (2006) OECD-FAO Agricultural Outlook. Rome, Italy.

24. Bender DA (2006) Benders' Dictionary of nutrition and food technology. (8thedn), Woodhead publishing limited. Cambridge, England.
25. Rusynyk RA, Still CD (2001) Lactose intolerance. J Am Osteopath Assoc 101 S10-20.

26. European Food Safety Authority/ EFSA (2010) Scientific opinion on lactose thresholds in lactose intolerance and galactosaemia. EFSA Journal.

27. Swallow DM (2003) Genetics of lactase persistence and lactose intolerance Annu Rev Genet 37: 197-219.

28. Sahi T (1994) Genetics and epidemiology of adult-type hypolactasia.Scand $J$ Gastroenterol Suppl 202: 7-20.

29. Wang Y, Harvey CB, Hollox EJ, Phillips AD, Poulter M, et al. (1998) The genetically programmed down-regulation of lactase in children. Gastroenterology 114: 1230-1236.

30. Paige DM, Davis LR (1985) Nutritional significance of lactose. I. Aspects of lactose digestion. In: Developments in Dairy Chemistry, Elsevier Applied Science, London 3: 111-132.

31. Mustapha A, Hertzler SR, Savaino DA (1997) Lactose: nutritional significance. In: Advanced Dairy Chemistry, Lactose, Water, Salts and Vitamins, (2ndedn) Chapman and Hall, London: 127-154.

32. Ingram CJE, Swallow DM (2009) Lactose Malabsorption. In: Advanced Dairy Chemistry Volume 3: Lactose, Water, Salts and Minor Constituents (3rdedn.). Springer SciencepBusiness Media, LLC, Ireland.

33. Bayoumi RA, Saha N, Salih AS, Bakkar AE, Flatz G, et al. (1981) Distribution of the lactase phenotypes in the population of the Democratic Republic of the Sudan. Hum Genet 57: 279-281.

34. Hijazi SS, Abulaban A, Ammarin Z, Flatz G (1983) Distribution of adult lactase phenotypes in Bedouins and in urban and agricultural populations of Jordan. Trop Geogr Med 35: 157-161.

35. Dissanyake AS, El-Munshid HA, Al-Qurain A (1990) Prevalence of primary adult lactose malabsorption in the eastern province of Saudi Arabia. Ann Saudi Med 10: 598-601.

36. Suarez F, Shannon C, Hertzler S, Savaiano D (2003) Lactose Intolerance. In Encyclopedia of food sciences and nutrition. Elsevier Science Ltd. USA.

37. Lomer MC, Parkes GC, Sanderson JD (2008) Review article: lactose intolerance in clinical practice--myths and realities.Aliment Pharmacol Ther 27: 93-103.

38. FAO (1990) The technology of traditional milk products in developing countries. Rome, Italy. 